\title{
Pollen analysis of core DS7-1SC (Dead Sea) showing intertwined effects of climatic change and human activities in the Late Holocene
}

Leroy S. A. G.

Institute for the Environment, Brunel University, Uxbridge (West London) UB8 3PH, UK

* Corresponding author: fax: +44-1895-269 761; email: suzanne.leroy@brunel.ac.uk

\section{Key words}

Dead Sea, human impact, late Holocene, climatic change, vegetation 


\section{Abstract}

The Dead Sea sediment holds the archives of a complex relationship between ever-changing nature and ancient civilisations. Here the detailed pollen analyses of core DS7-1SC (off-Ein-Gedi) are presented for the first time. The record covers the last 2500 years. The facies changes from halite (when no freshwater flows in the Dead Sea) to laminites (when rainfall provides sufficient inflow for the Jordan and subsidiary rivers) a couple of times through the record. The pollen diagram (supported by the facies change) shows a wetter Roman-Byzantine period, which allowed intensive arboriculture and a wetter period at the end of the $X I X^{\text {th }}$ and beginning of the $X X^{\text {th }}$ centuries, the latter in good relation with historical and instrumental data. Based on radiocarbon chronologies on several pollen diagrams along the western Dead Sea shore, the transition to drier climates and the transition to pastoralism are suggested to take place between a few decades before the Islamic period and close to this transition.

A high-resolution palynological study of the individual laminae forming the laminites (aragonite and gypsum in the summer versus detritics in winter) confirms the seasonal character of the laminae, but throws a note of caution as for their regular annual character. 


\section{Introduction}

The Dead Sea region (Near East, Fig. 1) has been intensively studied as it holds a complex and fascinating story of interaction between nature and past societies. It has been a very dynamic region over the last millennia, both in terms of its nature (climatic fluctuations and geohazards) and societal modifications (e.g. Leroy et al., in press). The influence of environmental changes on humans has been recognised as paramount. Drastic fluctuations of the Dead Sea water level have been measured (e.g. $28 \mathrm{~m}$ drop in the last century) and also reconstructed over the Late Pleistocene and Holocene (Bookman et al., 2006). Over the last 2500 years (yr), repetitive shifts of vegetation belts along the relatively steep slopes of the rift valley, occurred with changing precipitation (Enzel et al., 2003; Neumann et al., in press). Under those conditions, past societies may have suffered from a "ratchet effect" of vulnerability. This is when each succeeding event reduces the resources that a group or individual have to resist and recover from the next environmental shock or stress (Ford et al., 2006). In extreme cases, it may lead to societal collapse (Leroy, 2006). More precisely in the eastern Mediterranean area, during the transition from the Roman Empire to the Islamic period via the Byzantine period, a series of factors have fragilised past societies such as shift towards a more arid climate around $A D 550$, clustering of earthquakes in the $\mathrm{IV}^{\text {th }}$ to $\mathrm{VI}^{\text {th }}$ centuries, invasions into the Roman Empire and the plague of $A D 541$, radical changes in modes of food production (shift from dominant agriculture to dominant pastoralism) (Ken-Tor et al., 2001; Stiros, 2001; Hirschfeld, 2006).

The aims of this paper are the following. (1) The pollen diagram of core DS71SC, taken offshore Ein Gedi, is discussed here, details of which are presented for the first time. It provides a record of environmental changes over the last c. $2500 \mathrm{yr}$. The sediment of this sequence consists of two sedimentary units: massive halite and laminites (Heim et al., 1997). The climatic shift around AD 550 is especially discussed as well as the last decades. (2) Although sedimentology combined with radiocarbon dating have already suggested the annual character of the Dead Sea laminites, this seasonality is further examined by pollen analysis of individual laminae. 


\section{Modern settings}

Regional setting

The Dead Sea is the lowest water body in the world (Niemi and BenAvraham 1997). It is the Holocene surviving trace of a much larger Late Pleistocene lake, Lake Lisan (Bookman et al., 2006). Lake levels were until 1931 (date of the construction of a dam on the outlet of lake Kinneret, $100 \mathrm{~km}$ upstream of the Dead Sea) changing according to rainfall on the watershed (approximately $43,000 \mathrm{~km}^{2}$ ). Now with the added withdrawal of water for agriculture the level drop is c. $1 \mathrm{~m} \mathrm{yr}^{-1}$ (e.g. Dayan and Morin, 2006). Anati et al. (1995) have analysed the evolution of the Dead Sea stratification over the last 35 yr. Until 1978, the Dead Sea mostly was meromictic. However, since February 1979, it became holomictic with a December overturn and is only stratified and meromictic when there is a higher freshwater input due to either higher rainfall or a large release of water by the Degania dam (Gertman and Hecht, 2002). Moreover, a drastic change in the sedimentation in the Dead Sea took place in 1983 when the annual lamination was replaced by massive halite precipitation, this therefore followed the first complete mixing only by a few years (Anati, 1993). The basin is divided into two sub-basins separated by a topographic sill west of the Lisan peninsula at an elevation of $402 \mathrm{~m}$ bsl (Fig. 1). This configuration plays a central role in the lake-level history, because the southern basin acts as a large evaporation surface that can buffer lake-level rise.

The average annual rainfall over the Dead Sea itself is $\sim 90 \mathrm{~mm}$; but most of the water entering the lake comes from a zone of relatively high rainfall in the upper Jordan River watershed, with an annual precipitation in excess of $600 \mathrm{~mm}$ (Dayan and Morin, 2006). Rain occurs between October and May with often more rainfall at the transitional seasons (autumn and spring) and mostly in the form of rainstorms. The mean annual temperature east of Jerusalem (at Ma'ale Adumim, $330 \mathrm{~m}$ asl) is $19{ }^{\circ} \mathrm{C}$, whereas near the Dead Sea's northern tip it rises to $23^{\circ} \mathrm{C}$ (at Kalia, $60 \mathrm{~m} \mathrm{bsl}$ ) (Kutiel et al., 1995). Winds, a consequence of depressions during winter and spring, are mostly westerlies.

The main tributary to the Dead Sea is the Jordan River. Few perennial streams like Wadi el Mujib (Arnon) in Jordan opposite Ein Gedi, discharge into the lake (El-Naqa, 1993). Most of the wadis draining the Judean Mountains and the 
highlands of Moab and Edom are dry with the exception of winter floods from October to May. Springs such as Ein Feshkha, fed by aquifers from the Judean Mountains, emerge along the flanks of the Dead Sea (Ben-Itzhak and Gvirtzman, 2005).

There is a large difference between the northern head waters and the Dead Sea area climate. The catchment area drains both the Mediterranean and hyperarid climatic areas. As a consequence water level fluctuations mainly reflect precipitation changes in its much wetter headwaters.

\section{Vegetation}

The Dead Sea is surrounded by three altitudinal phytogeographic belts (Rossignol, 1969). First, along the Dead Sea itself, the Saharo-Sindian (= SaharoArabic) vegetation (dry hamada dominated by Chenopodiaceae) reaching north up to $50 \mathrm{~km}$ from the Dead Sea, with rare enclaves of Sudano-Deccanian vegetation (with tropical elements such as Acacia) linked to freshwater springs. Further up, Irano-Turanian vegetation is found on the slopes: a steppe with dwarf shrubs where Artemisia herba-alba then dominates. At still higher elevations, the Mediterranean vegetation is developed to the west on the Judean hills (1020 $\mathrm{m}$ a.s.I.) and to the east on the Moab hills (1065 m). The top of these hills is more than $1400 \mathrm{~m}$ higher than the present Dead Sea level. Where the vegetation climax is reached, the semisteppe is then replaced by evergreen maquis with Quercus calliprinos (evergreen oak) and Juniperus. It is because the Dead Sea is lying so low that the arid vegetation can reach so far north compared to other Middle-East regions. Neither oaks, nor olive trees are growing now in the Dead Sea trough. Wild olive trees are observed on the Mediterranean shores of Israel as far south as Mount Carmel, whereas wild grapes are not found south of Syria (Zohary and Spiegel-Roy, 1975). Recent plantations of oaks, Pinus halepensis and Cupressus sempervirens as well as exotic trees, Eucalyptus, Casuarina and others, have transformed the landscape. Carya pecan is cultivated in Israel (Keynan et al., 1991). These exotic trees reflect a period of extensive afforestation that took place between the two world wars.

The Middle East is one of the earliest centres of agriculture origins (Miller 1991). Over the millennia, the cultivated surface has gone through periods of extension and contraction. During the Roman-Byzantine times (from $63 \mathrm{yr} B C$ to $A D$ 
638), large farmsteads and intensive production for exportation (olive oil, dates, opobasalm and spices) have developed in addition to production for local use (Harland, 2002). This was followed by a drastic change to pastoralism sometimes around the Byzantine-Islamic transition.

\section{Air-borne pollen calendars}

One of the means to further constrain the seasonal character of laminites is by examining the pollen content of individual laminae. To constrain the present seasonal pollen content in the air, pollen calendars, prepared for problems of allergies, are used. The strongly contrasted rainfall pattern is reflected by the period of flowering of many plants. The flowering times of the thero-, geo- and hemicryptophytes occur in winter or in spring, whereas that of chamae- and phanerophytes are not confined to the rainy season alone (Zohary and Orshansky, 1949).

Pollen calendars from eighteen different sites show a clear sequence. A late winter and early spring bloom is observed for Cupressus (February-March), Quercus-Pistacia (February-March) and Olea (May) (Weinstein in Horowitz, 1979). Pinus and Gramineae blossoms are spread on a longer time period but peak in March. Chenopodiaceae are concentrated on late summer (August-September), Artemisia on the whole of autumn and Poterium spinosum on winter, especially January. More precisely in Jerusalem, most of the flowering occurs in February to May and to a lesser extent in October (Feinbrun et al., 1959): Pinus (March-April), Grasses (April-May), Olea (April-June), Poterium spinosum (January-March). Minor amounts of the following taxa have been trapped: Q. calliprinos (April-May), Asteraceae (March-May; some species blossom in autumn), Chenopodium (MayJune), and some rare grains of Amaranthaceae in autumn and winter. In the town of Arad (Judean desert), there are two main pollination seasons: spring (March and April) and autumn (September and October), with the strongest by far in spring (Kantor et al., 1966). In spring, the air content is dominated by Gramineae and Compositae, with also Cruciferae and Artemisia. In autumn, Artemisia dominates. In a pollen calendar from Amman, Jordan (Al-Eisawi and Dajani, 1988), peaks of Pinus and Juniperus occur in March, peaks of Oleaceae in May. Grasses, including cereals, and Chenopodiaceae are present all the year round, but are more 
abundant respectively in May and in July-August and October. A survey that ran for three years at Ein Boqeq (along the western coast of the south basin of the Dead Sea) by Y. Waisel (unpublished report) indicates also a strong seasonality, the dominance of Chenopods and especially a much lower pollen concentration than the rest of Israel.

\section{Past settings}

Previous palynological studies

Previous palynological studies covering the last $2500 \mathrm{yr}$ have been conducted in the area of the Dead Sea. The synthetic pollen diagrams of a sediment core from Ein Gedi (by Baruch and Bottema) and one from Sedom (by Bottema and Lanjouw), both covering about the last $3000 \mathrm{yr}$, appeared in Baruch (1990). The curves of four key taxa from core DS7-1SC by Leroy have been published in Heim et al. (1997) and 15 taxa in Neumann et al. (in press). More recent palynological investigations have been made in Ein Feshkha and in Ze'elim (Neumann et al., 2007). A comparison of these six diagrams can be found in Neumann et al. (in press). None of these studies, besides DS7-1SC, cover the period between World War II and 1993.

Regarding surface samples, the results of two analyses from a very short core taken at station 114 and one from a surface sample at station 22 , both nearby core DS7-1SC, can be found in Rossignol (1969). These samples were taken in 1959 when the Dead Sea was still forming a laminated sediment.

\section{Past lake levels}

The Near-East climate is changing according to shifting spheres of influence of various weather systems. Variations in lake levels reflected in the sediment forming in the Dead Sea and in vegetation may be due to shifts of cyclone tracks over the eastern Mediterranean region (Enzel et al., 2003). The Dead Sea having a large drainage basin reflects very well regional changes in precipitation.

One of the best records so far for sea level changes over the last $2500 \mathrm{yr}$ has been obtained from exposed sedimentary sequences along the western shores of the Dead Sea at the Ze'elim and the David fan-deltas (Fig. 2). The curve is based 
on identification of buried shoreline deposits within their sequences and their associated radiocarbon ages on organic debris (Enzel et al., 2003; Bookman et al., 2004, 2006). In brief, after a very low stand at less than $415 \mathrm{~m}$ bsl at $1400 \mathrm{yr}$ BC, the sea level has increased progressively over the centuries up to a maximum of $394 \mathrm{~m}$ at the beginning of the present era. The Hellenistic and Byzantine high stand (c. $250 \mathrm{yr} B C$ to AD 500) is interrupted by a brief low level at C. AD 270 down to 404 $\mathrm{m}$ bsl. The final end of this high stand comes well after the $\mathrm{V}^{\text {th }}$ century $A D$ and approximately corresponds to the Islamic conquest in the $\mathrm{VII}^{\text {th }}$ century AD. The levels then drop to below $406 \mathrm{~m}$ around AD 700, to re-increase and oscillate at $402-$ $399 \mathrm{~m}$ for a few centuries. A sedimentary unconformity caused by this low lake level is estimated to date from after the $\mathrm{V}^{\text {th }}$ to before the $\mathrm{XI}^{\text {th }}$ century. The levels have then increased dramatically up to $390 \mathrm{~m}$ in AD 1900. Since then, they have spectacularly dropped (Bookman et al., 2004, 2006). In 1976, the level fell below the level of the Lynch straits, therefore disconnecting the southern basin from the northern one (Gavrieli, 1997). Modern massive halite precipitation from the main Dead Sea body and the accumulation of halite sediments started in 1983 and continued at least until 1993 (Gavrieli, 1997).

Geological setting, coring and lamination

The Dead Sea lies in a pull-apart basin within a continental transform plate boundary (Garfunkel, 1981; Niemi and Ben-Avraham, 1997). A large part of the Pleistocene sediment of the Lisan formation and most of the non-halite facies of the Holocene sediment of the Dead Sea are laminated. The usual, but not mandatory, succession of three facies in a year is the following: clastics from river inflow in winter or runoff floods in the transition seasons (allogenous origin) and gypsum and/or aragonite by precipitation in summer (autochthonous origin) (Bentor and Vroman, 1960; Reid and Frostick 1993). A spectral analysis on seasonal sublaminae of the Lisan formation found periodicities typical of solar forcing (Prasad et al., 2004). More complicated laminations (complex laminae) have been observed too: e.g. light evaporitic ones with one or more thin detritic beds that could perhaps represent more than a year (Heim, 1998).

For the first time, in 1993, a series of sediment cores were obtained from the surface of the Dead Sea owing to a joint Israeli-German project. The water level 
was at $407 \mathrm{~m}$ bsl that year. Fourteen cores were recovered with a piston corer and a SELCORE percussion-coring device from the bottom of the northern basin of the Dead Sea (Fig. 1). Core DS7-1SC (in short DS7), $365 \mathrm{~cm}$ long, $12 \mathrm{~cm}$ in diameter, taken at $203 \mathrm{~m}$ bsl (level of 1993) was recovered from a rise adjacent to the western border fault of the Dead Sea graben. It is located northeast of Ein Gedi by $31^{\circ}$ 29.363' $\mathrm{N}$ and $35^{\circ} 26.101^{\prime} \mathrm{E}$ (Heim et al., 1997; Ben-Avraham et al., 1999). The lithology consists of an alternation of two units (Fig. 2) (Heim et al., 1997; Heim, 1998): from 365 to $320 \mathrm{~cm}$ the Lower Salt Unit (LSU), from 320 to $220 \mathrm{~cm}$ the Lower Laminated Unit (LLU), from 220 to $57 \mathrm{~cm}$ the Middle Salt Unit (MSU) with rare levels of finer grained salt, a level of salt with mud $(87$ to $73 \mathrm{~cm})$ and three levels of laminites $(195-194,174-173$ and 73 to $70 \mathrm{~cm})$, then a short coring gap estimated at $5 \mathrm{~cm}$, from 52 to $40 \mathrm{~cm}$ the Upper Laminated Unit (ULU) and finally from $40 \mathrm{~cm}$ to the surface the Upper Salt Unit (USU). Core DS7 represents well the other cores taken in the southern part of the north basin (Heim et al., 1997).

Four AMS ${ }^{14} \mathrm{C}$ dates on embedded plant fragments $(302.5 \mathrm{~cm}$ at $2270 \pm 105$ ${ }^{14} \mathrm{C}$ yr BP (ETH-15434), $280.5 \mathrm{~cm}$ at $2095 \pm 95{ }^{14} \mathrm{C}$ yr BP (ETH-15433), $273.5 \mathrm{~cm}$ at $1915 \pm 80{ }^{14} \mathrm{C}$ yr BP $(\mathrm{ETH}-13970)$ and $265.8 \mathrm{~cm}$ at $1765 \pm 75{ }^{14} \mathrm{C}$ yr BP $\left.(\mathrm{ETH}-15432)\right)$ provide an age for the LLU of core DS7 at roughly around $2000 \mathrm{yr}$ BP (Fig. 2) (full details in Heim et al., 1997; Heim, 1998). Their calibrated ages with a 95.4\% probability (Bronk Ramsey, 1995; 2001) are shown on figure 2. Further radiocarbon dates were derived from the upper part of the core giving ages from the $X X^{\text {th }}$ century to recent for the ULU. Details of the dates can be found in Heim et al. (1997). The laminite counting of the LLU in thin section (Heim, 1998) suggests a $0.36 \mathrm{~cm} \mathrm{yr}^{-1}$ sedimentation rate and an overall duration of c. $300 \mathrm{yr}$. This might be underestimated due to missing layers caused for example by lack of winter floods and erosion due to earthquakes and flash floods. The four radiocarbon dates place the LLU in the Roman period (Fig. 2) (Heim et al. 1997). Heim (1998) suggest the following dates for the lithological units: LSU at $450 \mathrm{yr} B C$ to AD 1, LLU at AD 1 350 (with a probable duration of $300 \mathrm{yr}$ based on a laminite count), MSU at AD 350 - 1650, and ULU from 1650 to an unspecified date. In addition, the known limnological changes of the $X X^{\text {th }}$ century firmly place the top of the ULU at 1983 (Heim et al., 1997). The latter paper to the contrary suggests based on vegetation 
history that the end of the LLU falls close to the end of the Byzantine period (see discussion).

Scanning electron microscopy (SEM) analysis and thin section studies of the LLU in core DS7 reveal that the white and light-grey laminae are composed of either 5-10 $\mu \mathrm{m}$ small aragonite needles or stellate aggregates, and euhedral pseudohexagonal gypsum crystals (20-50 $\mu \mathrm{m})$ (Heim et al., 1997). The dark green, dark grey and black laminae mainly consist of detrital silt and clay-sized components of subhedral calcite and quartz, as well as micritic limestone clasts and clay minerals derived from the Cretaceous-age escarpment. Lamination develops from alternating precipitation of aragonite or gypsum in summer and sedimentation of clastic and organic matter transported to the lake by episodic flood events in the wadis along the Dead Sea basin, for example after the typical Mediterranean heavy rainfall events during winter (Heim et al., 1997) or rain storms during the season transitions (autumn, spring).

\section{Material and methods}

In core DS7-1SC, the palynological subsampling (56 samples) has been made as follows. The laminites were subsampled every $3 \mathrm{~cm}$ in sections of 2 to 10 $\mathrm{mm}$ thick with volumes of $0.5-2.0 \mathrm{ml}$. In the salts, $5 \mathrm{~cm}$-long sections with a volume of $10-20 \mathrm{ml}$ have been taken at a considerably lower sampling resolution, every 13 $\mathrm{cm}$. A palynological study on samples containing only one type of sediment facies (lamina) has been carried out. Sampling was achieved by hand in the laboratory, while noting the thickness of the different lithologies (table 1). Seventeen samples have been analysed from two different pollen zones. In this specific case, owing to the lamination, the pollen concentration (pollen grains per $\mathrm{ml}$ ) is close to the influx of pollen grains per $\mathrm{ml}$ per season.

The samples were treated in three different laboratories (Université Catholique de Louvain, Queen's University of Belfast and University of Sydney) with the following sequence: pyrophosphate, $\mathrm{HCl}, \mathrm{HF}$ and $\mathrm{HCl}$, sieving at $10 \mu \mathrm{m}$. The treatment at UCL (only 4 samples) was based on heavy liquids (instead of HF) and no concentrations were calculated. In the two other laboratories, the concentration in number of pollen grains and spores per $\mathrm{ml}$ of wet sediment was obtained with the addition of Lycopodium spore tablets. 
The counts reach a base sum of at least 300 grains per sample for the calculation of reliable percentages. Out of the sum are the rare aquatic elements, the spores and the varia (unknown and indeterminable grains). 126 taxa were recognised in the diagram of core DS7. Pollen diagrams are plotted using the program Psimpoll 2.27 (Bennett, 2007). A cluster analysis, CONISS (a program for stratigraphically constrained cluster analysis by method of incremental sum of squares), available in the psimpoll package, has been run on core DS7 samples (Bennett, 2007). The zonation was obtained after square root transformation and with cutting at the level of 1.8 of dispersion. The pollen zones (pz) are made on 20 taxa above $3 \%$.

\title{
Results and interpretation
}

\author{
Core DS7-1SC
}

\section{Vegetation zone by zone}

The zonation is slightly different from that published in Heim et al. (1997) as different samples were included and a slightly different zonation method was used (e.g. square root transformation was not used in the earlier analysis): the main difference bears on a move downwards of the limit pzDS1/2 (Figs 3 and 4). Overall the pollen diagram is largely dominated by non-arboreal taxa, the majority consisting of Amaranthaceae-Chenopodiaceae (A-C) pollen (Figs 3 and 4). The sparse aquatics are composed of very rare Alisma, Potamogeton and Ranunculus acris- t., and somewhat more regular occurrences of Typha-Sparganium (Fig. 3). The spores are also sparse. Reworked pollen grains and spores are more frequent in pzDS3b and 3d. Fungal spores and dinoflagellate thecae are present in the laminated units. In general the concentration is very low in the salts, in the order of a few hundreds to a few thousands of grains per ml (Fig. 3), possibly due to both a higher sedimentation rate and a sparser vegetation cover. To the contrary, in both laminated sequences, the concentration often reaches more than 15,000 grains $\mathrm{ml}^{-}$ 1.

\section{PzDS1 from bottom to $293.2 \mathrm{~cm}$, rise of Olea}


The tree, or arboreal, pollen (AP) percentages are clearly dominated by Olea, whose values rise within pzDS1. There are some occurrences of Vitis pollen grains. The pollen spectra are largely dominated by A-C (with however decreasing values through this zone), followed by Artemisia, Poaceae, Asteraceae and Plantago. Mercurialis annua-t. has a continuous curve, up to a maximum of $4 \%$. It will remain present throughout the diagram but with lesser values $(<2.8 \%)$. Cerealia-t. grains are continuously recorded. In the first sample of this pz, the very open landscape is explained by the aridity at the end of the Iron Age perhaps already combined with an early human impact. In the following samples, agriculture, with Cerealia-t., Vitis and Olea, is progressively increasing on a background of Saharo-Arabic vegetation due to the close proximity of the desert.

\section{PzDS2 from 293.2 to $227.3 \mathrm{~cm}$, maximum of Olea}

Olea percentages are very high (above $20 \%$ ) throughout this pz with one peak at $30 \%$. There are more frequent counts of Juglans and Vitis. A-C percentages decrease and Artemisia values slightly increase towards the end of this $\mathrm{pz}$.

Sarcopoterium values progressively rise and become continuous. Overall this zone is characterised by a widespread cultivation of Olea, Vitis, Juglans and Cerealia-t.. Human impact on the landscape is intense.

\section{PzDS3a from 227.3 to $188.7 \mathrm{~cm}$, peak of Pinus}

The most important change is the drastic drop of Olea values to less than $10 \%$. It will remain so for the rest of the pollen diagram. Vitis is absent from now on. This pz is characterised by a bell-shaped peak of Pinus up to $10 \%$, which so dominates the arboreal taxa. The Pistacia curve becomes continuous and remains in this way up to pzDS3c. Sarcopoterium values show a continuous curve. After a brief peak of $15 \%$, Poaceae values drop down to $5 \%$. There is a fall in the Cerealiat. values. Plantago is frequently above $5 \%$ in pzDS1, 2 and 3a. Higher Artemisia percentages are noted at the transition pzDS 2/3a. This is clearly a transitional period. The fields are abandoned and colonised by Pinus, a pioneer tree. The fallow lands progressively become more steppic.

PzDS3b from 188.7 to $52.8 \mathrm{~cm}$, sparse Mediterranean vegetation and pastoralism

Pinus percentages have dropped back to ca $3 \%$ for the rest of the diagram. Q. calliprinos values distinctively increase from less than $3 \%$ to often more than $10 \%$. Sarcopoterium reaches its maximum values in pzDS3b and 3c. Artemisia 
percentages are high. It is therefore suggested that $Q$. calliprinos and other natural Mediterranean plants replace Olea on the Judean and Moab hills. Agriculture is largely supplanted by pastoralism. The steppe and the desert expand further.

PzDS3c from 52.8 to $37 \mathrm{~cm}$, deforestation and first exotics

Q. calliprinos percentages clearly drop. A-C and Artemisia values decrease.

Centaurea grains are frequent at the beginning and the other Asteraceae at the end of this zone. Poaceae and Plantago percentages form a very clear bell-shaped curve within this zone. There is a slight re-increase in Cerealia-t. values. Casuarina, Myrtaceae (likely Eucalyptus), trees introduced from the southern hemisphere, and Carya appear. This phase is interpreted as the results of a renewed agriculture. The Poaceae are caused by more agriculture and probably also by more rainfall.

Ruderal plants are more frequent. The oak formation is depleted. Human impact on the vegetation is strong again but not as much as in pzDS2.

$\underline{\text { PzDS3d from } 37 \mathrm{~cm} \text { to top, afforestation and diversification of weeds }}$

Cupressaceae have a continuous presence only in this zone. The highest values are reached in the last sample. Betula grains are frequent only in this $\mathrm{pz}$. There is a slight increase in the values of the $Q$. calliprinos. The AP rise again in the last sample. A-C percentages increase once more to the high values of pzDS1. Artemisia values are the lowest. Brassicaceae values are important, often up to $5 \%$. Rumex (in most of the diagram 2-3\%) now becomes rare. Sarcopoterium percentages suddenly decrease. Centaurea cyanus is an indicator of the presence of fields. Overall, the low percentages of Artemisia could be explained by its use for fuel. The Brassicaceae could be the result of cultivation. The weedy species are more diversified. Cupressaceae, Carya, Myrtaceae (Eucalyptus) and Casuarina are more widely planted.

\section{Lithological units and pollen zones}

Comparing the boundaries of the pollen zones and of the lithological units may highlight any lead or lag effects (Fig. 2). The transition of the LSU to the LLU (at $320 \mathrm{~cm}$ ) comes $27 \mathrm{~cm}$ before the transition of pzDS1 to 2 (at $293.2 \mathrm{~cm}$ ). Hence the development of agriculture has lagged behind the improvement of the environment (especially precipitation). The transition of LLU to MSU at $220 \mathrm{~cm}$ is within pzDS3a $(227.3-188.7 \mathrm{~cm})$. Hence the collapse of agriculture has taken place 
before the change in sedimentation type. These two observations suggest a great sensitivity of agriculture to precipitation. In other words, the phase of intense agriculture is completely enclosed within the phase of high lake levels. The boundaries of the ULU are quasi coincident with $p z D S 3 b / 3 c$, indicating in this case a more immediate link between environmental change and human activities change.

\section{Laminites}

Figure 5 displays selected pollen histograms for laminae taken in pzDS1 and pzDS2 separately as the difference between these two pollen zones (e.g. more A-C in DS1) is larger than the difference between the grey (gypsum) and the dark (detritics) laminae. In general the detrital layers contain more organic debris and broken parts of stamina. The following taxa are more abundant in the detrital layers as well: all Asteraceae, Brassicaceae and reworked grains, and to a lesser extent, Caryophyllaceae, M. annua-t., Typha-Sparganium and indeterminable grains. In the light laminae with dark beds as well as the gypsum lamina, Q. calliprinos, Olea, Poaceae, Cerealia-t. and Sarcopoterium are slightly more abundant. A-C, although dominant, fluctuate a lot, with however a trend to higher values in the gypsum layers both in pzDS1 and DS2 (with exception of sample $2821 \mathrm{~mm}$ ). The laminae with a pure aragonite facies (3056 and $3046 \mathrm{~mm}$ ) or a pure gypsum facies (3033 and 2817 $\mathrm{mm}$ ) were so poor or even sterile that they were not included in the pollen diagram (table 1). For the other samples, a diagram in concentration or influx has been prepared (not shown). The concentration does not vary much (values between 5000 and 12,000 grains $\mathrm{ml}^{-1}$ ) except for one detrital sample at $3064 \mathrm{~mm}$ with high values of c. 40,000 grains $\mathrm{ml}^{-1}$ (Fig. 5).

In the detrital laminae, the poorer pollen preservation, the higher percentages of transport and oxidation resistant pollen grains and the high number of stamina fragments indicate water transport in addition to air transport (Fig. 5 and table 1). This is not the case for the lighter laminae. In the two gypsum samples that provided pollen, there is a slightly higher value of $A-C$, which is a late spring and summer flowering plant. The absence of pollen in the aragonite layers and the absence or low concentrations observed in the totally gypsum layers indicate their formation in summer, when there is little pollen in the air and no river inflow.

Therefore the evidence is present for seasonality (especially for the aragonite and 
the detrital layers) but it would not be sufficient without the support of the mineralogical interpretation.

\section{Discussion}

\section{Past vegetation}

Vegetation changes can be caused both by human impact and precipitation fluctuations, these factors being usually difficult to disentangle. Nevertheless as lake level changes until the last century were mainly caused by precipitation, a more precise interpretation can be proposed for vegetation changes in the Dead Sea area. There is a strong human influence all through the sequence with indicators of agricultural activity, even often dominating the pollen diagram. A discussion of the pollen data of core DS7-1SC is presented here zone by zone under the light of other pollen diagrams, reconstructed lake levels and past climates. Ages are suggested for each zone (Fig. 4).

\section{PzDS1, Hellenistic period}

The LSU formed under arid conditions. The age of the section of pzDS1 within the LSU remains speculative: perhaps somewhere within the Persian period (Issar et al., 1991). The transition from LSU to LLU, based on Issar et al. (1991) could represent the end of this arid period at c. $500 \mathrm{yr}$ BC. The area was then under the end of the Persian military domination and at the beginning of the Greek colonisation. The Persians did invade the Near East but never really settled. The Greeks who followed them did on the contrary build up colonies and therefore changed the local agricultural system (Baruch, 1986). The lake levels are low during most of this pz, but increase at the end (Bookman et al., 2004).

\section{PzDS2, Romano-Byzantine period}

The Olea peak is dated from the Roman period in other pollen diagrams (Neumann et al., in press). Extensive olive cultivation is well known from the Hellenistic to the Byzantine period. Juglans occurrences are subcontinuous. The first appearance of Juglans pollen grain is considered in Europe as the sign for the beginning of the Roman influence (Huntley and Birks, 1983). The evidence for extensive agriculture characteristic of this zone might have began during the Hellenistic period but it certainly culminated during the Roman-Byzantine period, as 
in much of the Mediterranean world. The climate was more humid in the Dead Sea drainage as indicated by high lake levels (Bookman et al., 2004; Migowski et al., 2006). In the Mediterranean region, using archaeological and historical records (e.g. bridges over now-dry rivers and cities with massive water supply systems from sources now non-extant), as well as climate modelling (Yakir et al., 1994; Reale and Dirmeyer, 2000; Reale and Shukla, 2000), higher rainfall is reconstructed over the region connected to a northward shift of the Inter-Tropical Convergence Zone.

\section{PzDS3a, transition towards the beginning of early Islamic period}

The rather sudden drop in agricultural indicators slightly predates or is synchronous with the conquest of the Arabs (see discussion). Pinus peaks at the end of the cultivation period before re-installation of natural Mediterranean vegetation (Baruch, 1986). A date of AD 638 is suggested for the shift from Olea to Pinus in Neumann et al. (2007 and in press): the suggested causes are a combination of political change, aridification of the climate and change to pastoralism. Bookman et al. (2004) and Migowski et al. (2006), for this period, reconstruct a sharp drop in lake levels, which then remain low.

\section{PzDS3b, early Islamic period to Ottoman}

Baruch (1986) proposes that: "the decline of agriculture from the second half of the $1^{\text {st }}$ millennium AD onwards triggered a process of forest regeneration". This can be seen in the high values of the $Q$. calliprinos. Pollen diagrams on the whole do not distinguish many changes in this period, although low water levels with some high stands, probably minor, have been proposed (Bookman et al., 2004; Neumann et al., in press). In Wadi Faynan, southern Jordan, the Little Ice Age has been identified by an arid episode, causing widespread alluviation (Hunt et al., 2007).

PzDS3c, late Ottoman to 1983

The last deforestation is linked to charcoal making with a peak during the World War I for fuelling of military trains (Baruch, 1986). Towards the top of the pz(and ULS), pollen grains of exotic plants, such as Casuarina, Eucalyptus (Myrtaceae), Picea and Carya appear resulting from afforestation, clearly indicating that it cannot be older than AD 1850 (Baruch, 1986).

Rossignol's surface sediment taken in 1959 is in a mud on the first $40 \mathrm{~cm}$ (Rossignol 1969) most probably corresponding to the ULS. It is overlying salts corresponding to the MSS. She found similar content of Poaceae, Sarcopoterium 
and Plantago than in pzDS3c, and different from pzDS3d, confirming the extremely recent formation of USS. Rare only exotics were noted.

This $\mathrm{pz}$ is related to the observed high stand of late $\mathrm{XIX} \mathrm{X}^{\text {th }}$ century (Klein, 1965). Moreover, high lake levels from AD 1895 to 1933 correlate well with measured high rainfall on Jerusalem (records available since 1846; also Enzel et al., 2003).

PzDS3d, 1983-1993

The $X X^{\text {th }}$ century agriculture is hardly marked in the diagram although agricultural technology is at its maximum. The extremely low pollen concentrations can be best explained by the very fast sedimentation rate of the salts. A comparison to the other five pollen diagrams from the Dead Sea and to that of Lake Kinneret (Baruch, 1986) shows, because of the presence of the exotics in core DS7, that it is the first record covering the last millennia up to 1993.

In this period certainly and also to some extent in the preceding one, lake levels do not reflect climatic changes as the water extraction for human uses is overpowering (Dayan and Morin, 2006).

It is remarkable that the main change in the pollen diagram is caused by agriculture during the Roman and Byzantine periods (possibly slightly earlier). The two most arid periods (illustrated by the highest $\mathrm{A}-\mathrm{C} \%$ ) are at the bottom (first part of pzDS1) and the top (pzDS3d). The top one is linked to both human impact and modern agriculture whereas the lower one is linked to aridity mostly.

\section{Chronology}

One of the most relevant and critical ages to determine here is indeed that of the end of the Roman-Byzantine agricultural phase. A step in climatic aridification is widely recognised at $A D 550$ in a few well-dated sites. In Hoti cave, Oman, a $\partial^{18} \mathrm{O}$ record dated by the Uranium series shows a clear wetter phase between AD 1 and 540 (Fleitmann, pers. comm., 2008). In the Arabian Sea, a transition from a strong Indian monsoon to the present drier conditions dated by varve counting took place at 1500 cal. yr BP (Lückge et al., 2001). In the Libyan Desert, the pastoral state of the Garamantians falls when conditions become too dry at $1500 \mathrm{cal}$. yr BP as suggested by dendroclimatology (Cremaschi et al., 2006). Similar agricultural collapses to that observed in core DS7 are known from around the east 
Mediterranean area. The Beysehir Occupation Phase (van Zeist et al., 1975) defines a period of intensive agriculture that collapses in different places at different times but overall around AD 400-600 in SW and NW Anatolia (Eastwood et al., 1998; Leroy et al., 2002; Leroy, unpublished data). Pollen and isotopes in Lake Kinneret (Issar et al., 1991; Baruch, 1986) suggest a climatic deterioration towards the end of the Byzantine period with the end of the Olea phase dated by ${ }^{14} \mathrm{C}$ at $\mathrm{AD}$ 550. Kinneret

In the Levant, the $\mathrm{VI}^{\text {th }}$ century $\mathrm{AD}$ is still considered as a period of developed and productive agriculture, whereas the $\mathrm{VII}^{\text {th }}$ century shows a reversal of this trend (Hirschfeld, 2004). "The early Byzantine period witnessed the establishment of rural agriculture structures in remote and previously unsettled areas" (Hirschfeld, 2004). Along the shores of the Dead Sea, well-dated pollen diagrams such as the Ze'elim and Ein Feshkha pollen diagrams (Neumann et al., 2007) suggest an age of c. AD 638 for the transition between the phases of intensive agriculture with Olea and of Pine colonisation. Add a table with all the ages of all the sites. In brief for the Dead Sea area, this agricultural collapse is somewhere in the later part of the Byzantine period or at the transition to the Islamic period.

The correlation of the Dead Sea levels and core DS7 (Figure 8 of Bookman et al., 2004) suggests the LLU corresponds to the Roman period and the lowest muddier horizon in the MSU to the $\mathrm{IV}^{\text {th }} \mathrm{c}$. Byzantine period. However, because the correlation between six pollen diagrams along the west shore of the Dead Sea is very good (Neumann et al., in press) as well with the pollen diagram of Lake Kinneret (Baruch, 1986) +Birket Ram, the option of the transition pzDS2 to 3a in the $\mathrm{VI}^{\text {th }}$ or $\mathrm{VII}^{\text {th }}$ century is markedly preferred. Moreover as the highest (younger) sample from the LLU was collected from the middle of this unit (ETH-15432; Heim et al., 1997), it is possible that the upper part would have given a younger age; therefore also implying the pollen boundary must be corresponding to the end of the Byzantine period. Therefore the cultural classification remains close to that suggested previously in Heim et al. (1997) leaving the Byzantine period within the LLU.

Seasonal laminae 
Few pollen analyses have been made in individual laminae of annual laminites (or varves), usually due to the extremely small thicknesses of sediment involved. There are however a few exceptions, all showing nice alternation of pollen spectra in the dark and light layers or even when finer subsampling was possible successive blooms of plants through the year (Müller 1974; Peglar et al. 1984; Lotter 1991; Card 1997; St Jacques et al. 2008).

The lamination in the core DS7 is generally thicker than in the previous cases but involves more diverse successions of mineralogies (Fig. 5). One of the best signals in the present study is the pollen concentration (not measured in the other case studies) due to the strong seasonality of the rains in this part of the Middle East. It is however difficult to establish for sure if the samples with an aragonite or gypsum colour interspersed by thin detrital beds are only formed in one summer or over several years with very thin winter layers (resulting from insufficient winter rain).

In conclusion, more samples would be required to confirm the annual character of the lamination, although it seems clear that the gypsum and the aragonite layers have formed during the summer. Many exceptions seem to exist to the simple regular dark (winter) - light (summer) alternation, with perhaps the absence of some laminae and the doubling of others in some years. The direct use of laminae for establishing chronologies would require more multidisciplinary research including observations on the present.

\section{Conclusions}

During the time period covered by core DS7-1SC, i.e. the last $2500 \mathrm{yr}$, climate changes in the Levant are closely intermingled to human impact on the landscape. The sediment forming in the Dead Sea before the late $X X^{\text {th }}$ century is however a relatively direct reflection of rainfall, whereas vegetation changes are by and large influenced by human activities. The lithological response to hydrological changes (lamination versus massive salts) in core DS7-1SC can be roughly correlated with two of the three main lake-level changes recorded by palaeolimnological data, geomorphology and historical documents: the Roman-Byzantine period and the late $X I X^{\text {th }}$ and early $X X^{\text {st }}$ century. The middle high lake level of $A D$ 
$1200-1700$ is not clearly marked (maybe one of the upper muddier units in the Middle Salt Unit) and this might be due to a question of threshold for the proxies used. The main changes in the pollen spectra have been caused by the intense Olea cultivation in the Roman-Byzantine period and its collapse around the end of the Byzantine period. Similar spectacular changes have been observed in five other pollen diagrams on the west coast of the Dead Sea (Neumann et al., in press) and one from Lake Kinneret (Baruch, 1986). The precise age of this collapse of agriculture is quasi-synchronous to the change over to the Islamic period, although it may have happened as early as up to one century beforehand and be linked to the progressive aridification of the region at that time. It is not unlikely that such a sharp change in vegetation is a reflection of more than just climatic change and includes other factors: natural hazards, epidemics and social changes.

Although the seasonal formation of the laminites of the Dead Sea has been confirmed by change in taxa percentages, it is however the pollen concentration that provides the best signal with the summer layers (gypsum or aragonite) being very poor or even barren in pollen.

\section{Acknowledgements}

The first author is grateful to the GeoForschungsZentrum-Potsdam (Germany) for funding the pollen analyses of core DS7-1SC. M. Turner (Brunel University) has kindly revised the English of a draft of the manuscript.

\section{References}

Al-Eisawi, D., Dajani, B., 1988. Airborne pollen of Jordan. Grana 27, 219-227. Anati, D., 1993. How much salt precipitates from the brines of a hypersaline lake? The Dead Sea as a case study. Geochim. Cosmochim. Acta 57, 2191-2196.

Anati, D. A., Gavrieli, I., Oren, A., 1995. The residual effect of the 1991-93 rainy winters on the Dead Sea stratification. Isr. J. Earth Sc. 44, 63-70.

Baruch, U., 1986. The Late Holocene vegetational history of Lake Kinneret (Sea of Galilee), Israel. Paléorient 12, 37-48.

Baruch, U., 1990. Palynological evidence of human impact on the vegetation as recorded in Late Holocene lake sediments in Israel. In: Bottema, S., Entjes- 
Nieborg, G., Van Zeist, W. (Eds.), Man's role in the shaping of the eastern Mediterranean landscape. Balkema, Rotterdam, pp. 283-293.

Ben-Avraham, Z., Niemi, T. M., Heim, C., Negendank, J. F. W., Nur, A., 1999. Holocene stratigraphy of the Dead Sea: Correlation of high-resolution seismic reflection profiles to sediment cores. J. Geophys. Res. 104, B8, 17617-17625.

Ben-Itzhak, L., Gvirtzman, H., 2005. Groundwater Flow Along and Across Structural Folding: An Example from the Judean Desert, Isr. J. Hydrol. 312, 51-69.

Bennett, K., 2007. Documentation for Psimpoll 2.27 and Pscomb 1.01. http:// www.chrono.qub.ac.uk/psimpoll/psimpoll.html

Bentor, Y. K., Vroman, A., 1960. The geological map of Israel, 1:100,000. Sheet 16, Mt. Sedom: Jerusalem. Geological Survey of Israel $117 \mathrm{p}$.

Bookman (Ken-Tor), R., Enzel, Y., Agnon, A., Stein, M. 2004. Late Holocene lake levels of the Dead Sea. Geol. Soc. Am. Bull. 116, 5/6, 555-571.

Bookman, R., Bartov, Y., Enzel, Y., Stein, M., 2006. Quaternary lake levels in the Dead Sea basin: Two centuries of research. In: Enzel, Y., Agnon, A., Stein, M. (Eds), New Frontiers in Dead Sea Paleoenvironmental Research. Geol. Soc. Am., Special paper 401, pp. 155-170.

Bronk Ramsey, C., 1995. Radiocarbon calibration and analysis of stratigraphy: The OxCal program. Radiocarbon 37, 425-430.

Bronk Ramsey, C., 2001. Development of the radiocarbon calibration program OxCal. Radiocarbon 43, 355-363.

\section{Card}

Cremaschi, M., Pelfini, M., Santilli, M., 2006. Cupressus dupreziana: a dendroclimatic record for the middle-late Holocene in the central Sahara. The Holocene 16, 293-303.

Dayan, U., Morin, E., 2006. Flash Flood-Producing rainstorms over the Dead Sea, Israel: A Review, in: Enzel, Y., Agnon, A., Stein, M. (Eds), New Frontiers in Dead Sea paleoenvironmental research. Geol. Soc. Am., Special Paper 401, pp. 53-62

Eastwood, W. J., Roberts, C. N., Lamb, H. F., 1998. Palaeoecological and archaeological evidence for human occupance in southwest Turkey: the Beysehir Occupation Phase. Anatolian Studies 48, 69-86.

El-Naqa, A., 1993. Hydrological and hydrogeological characteristics of Wadi el Mujib catchment area, Jordan. Environm. Geol. 22, 257-271.

Enzel, Y., Bookman (Ken-Tor), R., Sharon, D., Gvirtzmann, H., Dayan, U., Ziv, B., 
Stein, M., 2003. Late Holocene climates of the Near East deduced from Dead Sea level variations and modern regional winter rainfall. Quat. Res. 60, 263-273.

Feinbrun, N., Rahat, A., Tas, J., 1959. Further studies in atmospheric pollen in Jerusalem. Bull. Res. Counc. 8D, 31-40.

Ford, J. D., Smit, B., Wandel, J., 2006. Vulnerability to climate change in the Arctic: A case study from Arctic Bay, Canada. Glob. Environm. Ch. 16, 145-160.

Garfunkel, Z., 1981. Internal structure of the Dead Sea leaky transform (rift) in relation to plate kinematics. Tectonophysics $80,81-108$.

Gavrieli, I., 1997. Halite deposition from the Dead Sea: 1960-1993. In: Niemi ,T. M., Ben-Avraham, Z., Gat, J., (Eds), The Dead Sea: The lake and its settings. Oxford University Press, New York, pp. 161-170.

Gertman, I., Hecht, A., 2002. The Dead Sea hydrography from 1992 to 2000. J. Mar. Syst. 35, 169-181.

Harland, P. A., 2002. The Economy of First Century Palestine: The State of Scholarly Discussion. In: Blasi, A. J., Turcotte, P.-A., Duhaime, J. (Eds), Handbook of Early Christianity: Social Science Approaches. Walnut Creek, CA: Alta Mira Press, pp. 511-527.

Heim, C., 1998. Holozäne Sedimente aus dem Toten Meer als PaläoklimaIndikatoren, Scientific Technical Reports, GeoForschungsZentrum Potsdam, 98/12.

Heim, C., Nowaczyk, N., Negendank, J., Leroy, S. A. G., Ben-Avraham, Z., 1997. Middle-East desertification: evidence from the Dead Sea. Naturwissenschaften 84, 398-401.

Hirschfeld, Y., 2004. A climatic change in the early Byzantine period? Some archaeological evidence. Palest. Explor. Quart. 136, 2, 133-149.

Hirschfeld, Y., 2006. The crisis of the sixth century: climatic change, natural disasters and the plague. Mediterr. Archaeol. Archaeom. 6, 19-32.

Horowitz, A., 1979. The Quaternary of Israel. Academic Press, New York. Hunt, C.O., Gilbertson, D.D., El-Rishi H.A., 2007. An 8000-year history of landscape, climate, and copper exploitation in the Middle East: the Wadi Faynan and the Wadi Dana National Reserve in southern Jordan. Journal of Archaeological Science 34 (2007) 1306-1338. 
Huntley, B., Birks, H.J.B., 1983. An Atlas of Past and Present Pollen Maps for Europe: 0-13,000 BP Years Ago. Cambridge University Press, Cambridge, p. 667.

Issar, A., Govrin, Y., Geyh, M., Wakshal, E., Wolf, M., 1991. Climate changes during the Upper Holocene in Israel. Isr. J. Earth Sc .40, 219-223.

Kantor, Z., Frank, M., Hoch-Kantor, D., Barkai-Golan, R., Marian, D., Schachnner, E., Kessler, A., de Vries, A., 1966. Airborne allergens and clinical response of asthmatics in Arad, a new town in a desert area in Israel. J. Allergy 37, 2, 65-74.

Ken-Tor, R., Enzel, Y., Stein, M., Marco, S., Negendank, J., 2001. High-resolution geological record of historic earthquakes in the Dead Sea basin. J. Geophys. Res. 106, B2, 2221-2234.

Keynan, N., Waisel, Y., Shomer-llan, A., Goren, A,. Brener, S., 1991. Annual variations of air-borne pollen in the coastal plain of Israel. Grana 30, 477-480.

Klein, C., 1965. On the fluctuations of the level of the Dead Sea since the beginning of the $19^{\text {th }}$ century. State of Israel. Hydrological Service. Hydrological paper 7.

Kutiel, P., Lavee, H., Shoshany, M., 1995. Influence of a climatic gradient upon vegetation dynamics along a Mediterranean-arid transect. J. Biogeogr. 22, 10651071.

Leroy, S. A. G., 2006. From natural hazard to environmental catastrophe, past and present. Quat. Int. 158, 4-12.

Leroy, S. A. G., Kazancı, N., Ileri, Ö., Kibar, M., Emre, O., McGee, E., Griffiths, H. I., 2002. Abrupt environmental changes within a late Holocene lacustrine sequence south of the Marmara Sea (Lake Manyas, N-W Turkey): possible links with seismic events. Mar. Geol. 190, 531-552.

Leroy, S. A. G., Marco, S., Bookman, R., Miller, Ch. S., in press. Impact of earthquakes on agriculture during the Roman-Byzantine period from pollen records of the Dead Sea laminated sediment. Quaternary Research

Lotter, A. F., 1989. Evidence of annual layering in Holocene sediments of Soppensee, Switzerland. Aquatic Sciences 51, 19-30.

Lückge, A., Doose-Rlinski, H., Khan, A. A., Schulz, H., von Rad, U., 2001. Monsoonal variability in the northeastern Arabian Sea during the past 5000 years: geochemical evidence from laminated sediments, Palaeogeogr., Palaeoclimatol., Palaeoecol. 167, 273-286. 
Migowski, C., Stein, M., Prasad, S., Negendank, J. F. W., Agnon, A., 2006.

Holocene climate variability and cultural evolution in the Near East from the Dead Sea sedimentary record. Quat. Res. 6, 421-431.

Miller, N., 1991. The Near East. In: van Zeist, W., Wasylikowa, K., Behre, K. E. (Eds), Progress in Old World palaeoethnobotany. Van Balkema, Rotterdam, pp. 133-167.

Müller, H., 1974. Pollenanalytische Untersuchungen und Jahresschichtenzählungen and der holstein-zeitlichen Kieselgur von Munster-Breloh. Geol. Jb. A21, 107-140.

Neumann, F. H., Kagan, E. J., Leroy, S. A. G., Baruch, U., in press. Vegetation history and climatic fluctuations on a transect along the Dead Sea west shore and their impact on past societies over the last 3500 years. J. Arid Environm. Nov. 2008.

Neumann, F. H., Kagan, E. J., Schwab, M. J., Stein, M., 2007. Palynology, sedimentology and palaeoecology of the late Holocene Dead Sea. Quat. Sc. Rev. 26, 1476-1498.

Niemi, T. M., Ben-Avraham, Z., 1997. Active tectonics in the Dead Sea Basin. In: Niemi ,T. M., Ben-Avraham, Z., Gat, J., (Eds), The Dead Sea: The lake and its settings. Oxford University Press, New York, pp. 73-81.

Peglar

Prasad, S., Vos, H., Waldmann, N., Goldstein, S., Stein, M., 2004. Evidence from Lake Lisan of solar influence on decadal- to centennial-scale climate variability during marine oxygen isotope stage 2 . Geology 32, 7, 581-584.

Reale, O., Dirmeyer, P., 2000. Modeling the effects of vegetation on Mediterranean climate during the Roman Classical Period. Part I: Climate history and model sensitivity. Glob. Planet. Ch. 25, 163-184.

Reale, O., Shukla, J., 2000. Modeling the effects of vegetation on Mediterranean climate during the Roman classical period. Part II: Model simulation. Glob. Planet. Ch. 25, 185-214.

Reid, I., Frostick, L., 1993. Late Pleistocene rhythmite sedimentation at the margin of the Dead Sea Trough: a guide to palaeoflood frequency. In: McManus, J., Duck, R. (Eds), Geomorphology and sedimentology of lakes and reservoirs. J. Wiley and sons, pp. 259-273.

Rossignol, M., 1969. Sédimentation pollinique récente dans la Mer Morte. Pollen et Spores 9, 17-38. 
St. Jacques, J.-M., Cumming, B. F., Smol, J. P., 2008. A statistical method for varve verification using seasonal pollen deposition. J. Paleolimnol. 40, 733-744.

Stiros, S. C., 2001. The AD 365 Crete earthquake and possible seismic clustering during the fourth to sixth centuries $A D$ in the Eastern Mediterranean: a review of historical and archaeological data. J. Struct. Geol. 23, 545-562.

van Zeist, W., Woldring, H., Stapert, D., 1975. Late Quaternary vegetation and climate of southwestern Turkey. Palaeohistoria 17, 55-143.

Waisel Y, unpublished report. Survey of Allergenic Airborne Pollen and Spores in the Dead Sea region 199-2002. www.deadseahealth.org/new_html/Microsoft\%20Word\%20-\%20Ssurveyofallergenic.pdf Yakir, D., Issar, A., Gat, J., Adar, E., Trimborn, P., Lipp, J., $1994 .{ }^{13} \mathrm{C}$ and ${ }^{18} \mathrm{O}$ of wood from the Roman siege ramparts in Masada (AD 70-73) provide evidence for a less arid climate for the region. Geochim. Cosmochim. Acta 58, 3535-3539.

Zohary, M., Orshansky, G., 1949. Structure and ecology of the vegetation in the Dead Sea region of Palestine. J. Botany 4, 177-206.

Zohary, D., Spiegel-Roy, P., 1975. Beginnings of fruit growing in the Old World. Science 187, 319-327. 


\section{Table}

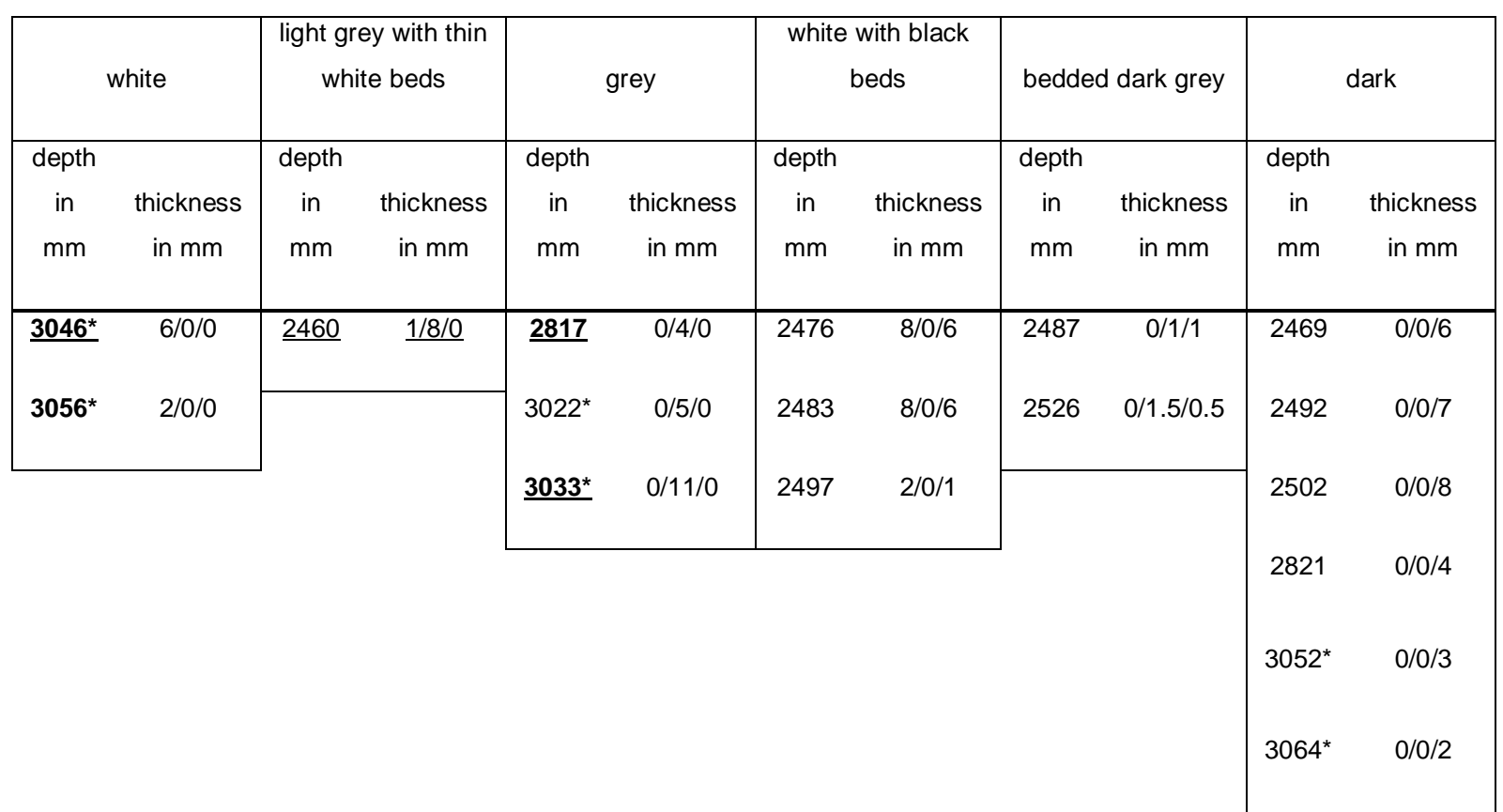

Table 1 


\section{Captions}

- Fig. 1: Location of the sites in the Dead Sea region. Insert: location of the Dead Sea in the Near East. DST = Dead Sea Transform Fault. Black square: location of core DS7-1SC.

- Fig. 2: Link between archaeological and historical periods and the lithozones of core DS7-1SC. LSU = Lower Salt Unit, LLU = Lower Laminated Unit, MSU = Middle Salt Unit, ULU $=$ Upper Laminated Unit, USU $=$ Upper Salt Unit. Grey strips in the lithological column $=$ muddier layers in the salt.

- Fig. 3: Detailed pollen diagram of core DS7-1SC. 10 x exaggeration curve.

- Fig. 4: Pollen and spore diagram for core DS7-1SC. Selected pollen curves only. $10 \times$ exaggeration curve. Lithological units: see caption of Figure 2.

- Fig. 5: Pollen and spore diagram for selected laminae in pzDS1 and 2, core DS71SC. Selected curves. Lithology in table 1.

- Table 1: Lithology of selected laminae based on visual inspection in pzDS1 and 2, core DS7-1SC. In bold: too poor to show sample in Fig. 5. In underlined: samples

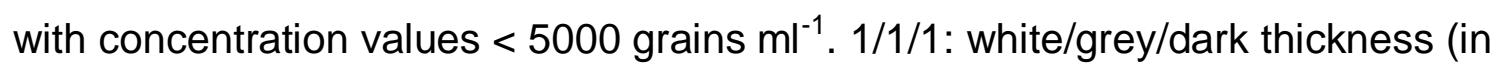
$\mathrm{mm}$ ) in each the sample. Asterisk: samples from pzDS1. 